\title{
COMBINED TREATMENT OF RUPTURED MIDDLE CEREBRAL ARTERY ANEURYSM FOLLOWED BY SUBARACHNOID HEMORRHAGE AND ACUTE SUBDURAL HEMATOMA IN MULTIPLE ANEURYSM DISEASE OF CEREBRAL BLOOD VESSELS: CASE REPORT
}

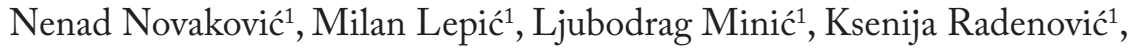 \\ Ante Rotim ${ }^{2}$ and Lukas Rasulić ${ }^{3}$ \\ ${ }^{1}$ Department of Neurosurgery, Military Medical Academy, Belgrade, Serbia; \\ ${ }^{2}$ School of Medicine, University of Rijeka, Rijeka, Croatia; \\ ${ }^{3}$ Clinical Department of Neurosurgery, Clinical Center of Serbia, Belgrade, Serbia
}

\begin{abstract}
SUMMARY - Aneurysms of blood vessels at the base of the brain are pathological focal outpouchings, usually found at the branching points of the arteries. Aneurysm can remain silent for life. Clinical presentation is due to rupture and bleeding. In only $1.3 \%$ of cases it results in subdural hematoma, which is associated with direct interaction of the aneurysm with the basal arachnoid membrane. Multiple aneurysms are present in $15 \%$ to $33 \%$ of cases with subarachnoid hemorrhage. Assessment of these patients is more complicated, as there are no specific signs to pinpoint/detect the aneurysm that has ruptured. This report presents a 44-year-old female patient suffering from multiple cerebral aneurysm disease, who was urgently treated after rupture by both endovascular (for multiple aneurysms) and surgical (for acute subdural hematoma) approach in the same act under general anesthesia, which resulted in complete recovery of the patient.
\end{abstract}

Key words: Intracranial aneurysm; Rupture - therapy; Subdural hematoma; Case reports

\section{Introduction}

Aneurysms of blood vessels at the base of the brain are pathological focal outpouchings, usually found at the branching points of the arteries. Aneurysm can remain silent for life ${ }^{1}$. Clinical presentation is due to rupture and bleeding (rarely due to compressive effect $)^{2}$. The rupture leads to subarachnoid hemorrhage (SAH) in most cases ${ }^{3}$, and in only $1.3 \%$ results in subdural hematoma $(\mathrm{SDH})^{4}$. The development of a $\mathrm{SDH}$

Correspondence to: Prof. Lukas Rasulić, MD, PhD, School of Medicine, University of Belgrade, Clinical Department of Neurosurgery, Clinical Center of Serbia, Višegradska 26, 11000 Belgrade, Serbia

E-mail: lukas.rasulic@gmail.com

Received April 22, 2015, accepted October 20, 2015 from a rupture is associated with direct interaction of the aneurysm with the basal arachnoid membrane ${ }^{5}$.

Multiple aneurysms are present in 15\% to 33\% of cases with $\mathrm{SAH}^{6}$. Risk factors associated with multiple aneurysms are hypertension, smoking and family history, especially in postmenopausal women ${ }^{7}$. Assessment of these patients is more complicated, as there are no specific signs to pinpoint/detect the aneurysm that has ruptured ${ }^{8}$.

The International Subarachnoid Aneurysmal Trial showed significant advantage of endovascular coiling over surgical clipping of aneurysms $s^{9,10}$, although controversy persisted over which modality of treatment should be chosen. Various factors dictate the type of treatment to be used ${ }^{11}$. 
This report describes a 44-year-old female patient with multiple cerebral aneurysm disease, who presented with severe spontaneous headache with nausea and vomiting, in soporous state, confused, and with no gross motor deficits or lateralization.

\section{Case Report}

The patient was admitted to the Military Medical Academy Emergency Department on July 21, 2010, because of a sudden, severe headache with nausea and vomiting, soporous, confused, and with no gross motor deficits or lateralization (Glasgow Coma Scale (GCS) 13). The blood pressure measured initially was $130 / 80$ $\mathrm{mm} \mathrm{Hg}$ and the patient was referred for multi-slice computerized tomography (MSCT) of the head with angiography of the cerebral blood vessels.

The patient's previous medical history revealed that it was not the first attack, as she had been treated before for rupture of the aneurysm at division of the basilar artery (BA) followed by SAH and intracerebral hematoma in the region of the right thalamus, when embolization of the ruptured aneurysm had been performed. The presence of multiple intracranial aneurysms was also found, and the second act was planned for August 2010.

During MSCT, deterioration of the patient's general state and consciousness occurred. The patient was referred to the surgical Intensive Care Unit (ICU) immediately. She was comatose, opened her eyes on rough stimuli, the right pupil was mydriatic with no reaction to the light and accommodation, and there was no adequate verbal response, with flexion of the left side limbs and plegia of the limbs on the right side (GCS 7). According to Hunt and Hess classification, the patient fell into the fourth group ${ }^{12}$.

Multi-slice computerized tomography revealed signs of acute subdural hematoma in the region of Sylvian fissure, of about $13 \mathrm{~mm}$ in thickness, signs of $\mathrm{SAH}$ in the same region, and a $14-\mathrm{mm}$ mid-sagittal structure shift (Fig. 1). Angiographic examination showed saccular aneurysm at the bifurcation of the right middle cerebral artery (MCA) of $4.3 \mathrm{~mm}$ in size, with the $2.1 \mathrm{~mm}$ wide neck, aneurysm in the anterior communicating artery $(\mathrm{ACoA})$ of $4.3 \mathrm{~mm}$ in size with the $1.7 \mathrm{~mm}$ wide neck, and two aneurysmatic narrowings in the middle segment of basilar artery (BA), with the right one $3.6 \mathrm{~mm}$ (neck width $2 \mathrm{~mm}$ ) and the left

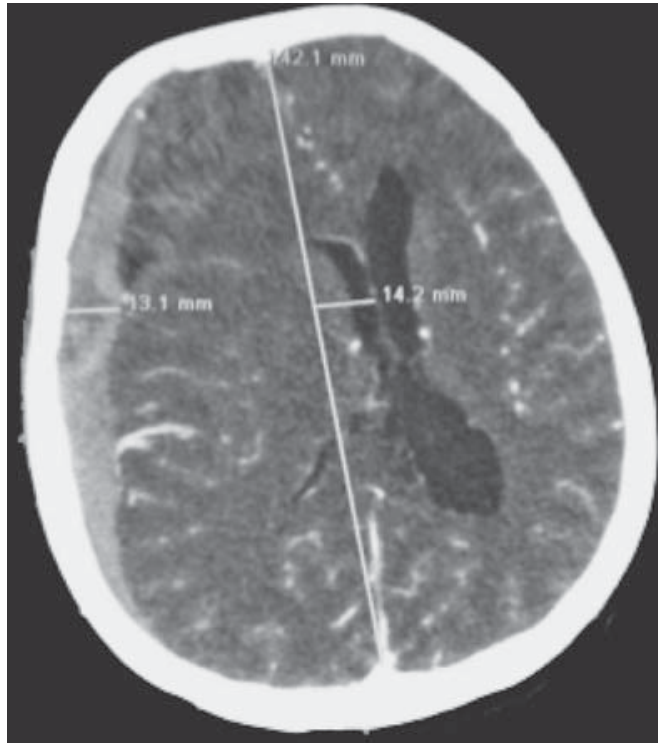

Fig. 1. Subdural hematoma after aneurysm rupture.

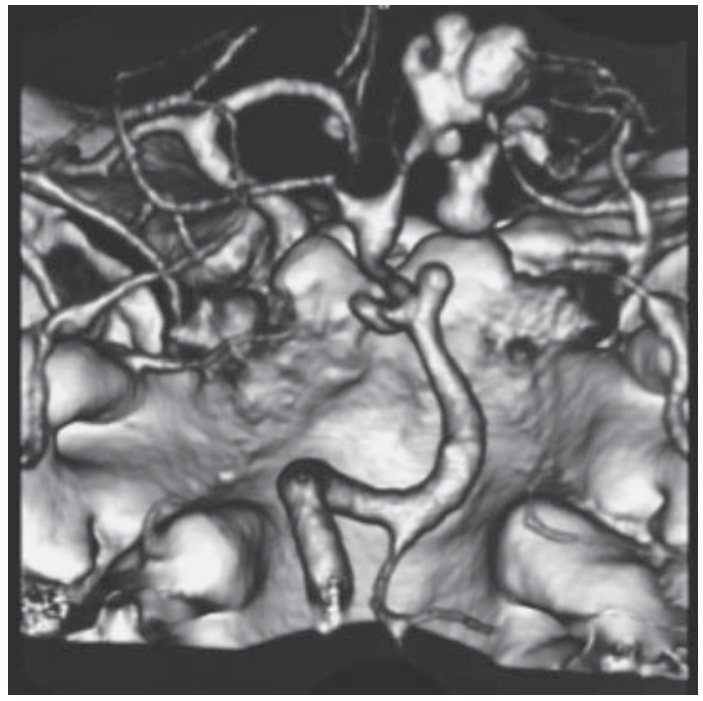

Fig. 2. Multi-slice computerized tomography with angiography showing bilateral aneurysms of basilar artery.

one $2.3 \mathrm{~mm}$ in size (neck width $1.8 \mathrm{~mm}$ ), and embolized aneurysm at the BA bifurcation (Fig. 2).

Since there were multiple cerebral aneurysms, it was not clear which one had ruptured. A large amount of fresh blood in the subdural space, combined with worsening of the patient's neurological and general state, led to the decision to perform digital subtraction angiography (DSA) in general anesthesia to locate the ruptured aneurysm(s), perform embolization, and only then to proceed to open surgery. Introduction to general anesthesia was done in the ICU, and the patient 


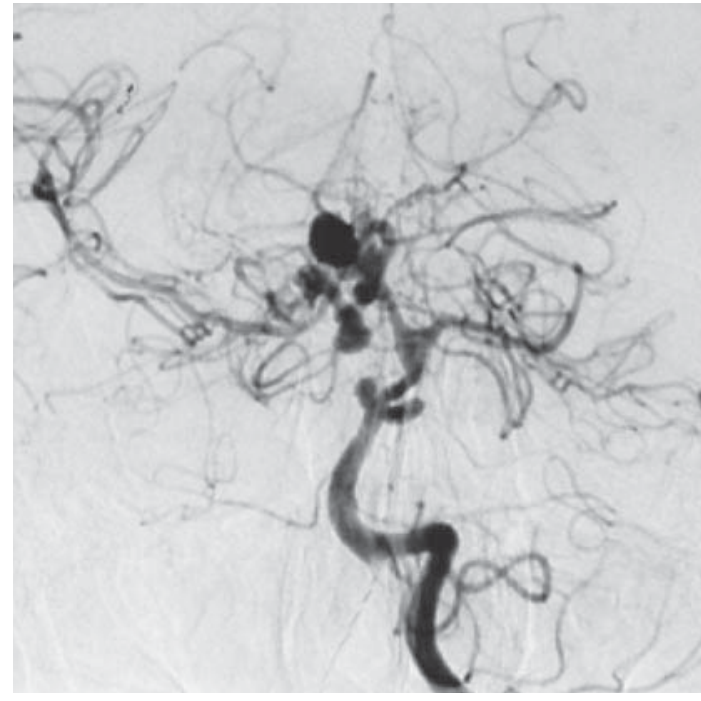

Fig. 3. Digital subtraction angiography showing multiple aneurysms.

proceeded to DSA and embolization. The ruptured aneurysm was at the division of the right MCA, where significant vasospasm of the whole right MCA branching was also noted (Fig. 3).

The ruptured aneurysm was embolized, followed by the patient's transfer to the operating room for parietal decompressive craniotomy on the right side with evacuation of acute SDH. A large cerebral edema was noted intraoperatively, and it was decided not to put back the bone operculum in order to relax the brain. Immediately after the surgery, the patient was transferred to the surgical ICU, where she was treated using the triple-H therapy protoco ${ }^{13}$. MSCT was performed on the next day, showing the state after surgery and significant brain edema (Fig. 4).

Seven days of intensive therapy led to improvement of the patient's general condition, as well as of the state of consciousness. The patient kept her eyes open spontaneously, executed orders, but no verbal response was established. Gross motor deficit in the form of hemiplegia of the left side limbs persisted.

During the patient's stay in the Department of Neurosurgery, one month after the bleeding, deterioration of consciousness developed. MSCT of the head showed signs of hydrocephalus with perifocal edema around the ventricles. Ventriculoperitoneal shunt using programmable valve was implanted and set to 120 $\mathrm{mm} \mathrm{Hg}$, which was followed by improvement of her neurological and general state ${ }^{14}$. Two weeks after the

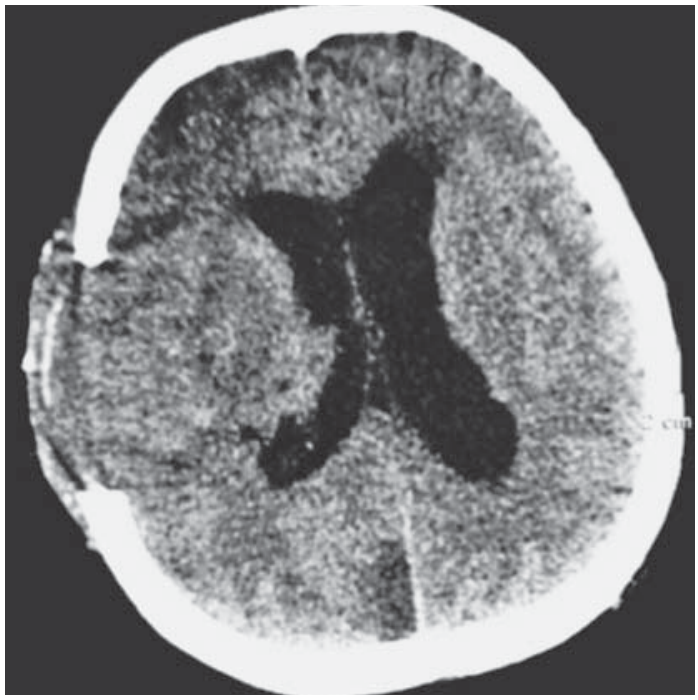

Fig. 4. Postoperative state with brain edema.

implantation of the shunt, the patient was conscious, communicative, hemodynamically stable, gross motor deficit persisted in the form of left side limb hemiplegia, and she was referred to a rehabilitation center where she continued physical treatment.

\section{Discussion}

Aneurysm rupture in multiple cerebral aneurysm disease manifesting as $\mathrm{SDH}$ with $\mathrm{SAH}$ is rare ${ }^{4,15}$, as is the combined endovascular and surgical treatment for the condition ${ }^{16}$. The main dilemma was whether the patient should undergo surgery immediately, or the MSCT finding should be supplemented with DSA to differentiate the ruptured aneurysm with certainty. With DSA in general anesthesia, it was possible to perform embolization in the same act and proceed to surgery with a much lower chance of rebleeding.

Patients with cerebral aneurysm ruptures that develop large hematomas (either intracerebral or subdural), especially those with significant mid-sagittal structure shift and in poor clinical state, are considered in general to be candidates for an open surgical rather than endovascular treatment, for decompression in addition to ruptured aneurysm treatment ${ }^{12,17}$.

In conclusion, in our patient, the combined treatment led to drastic recovery regardless of the disease complexity and poor neurological and clinical state. Good decision making on diagnostic and treatment modalities and appropriate interventions performed in 
the early period, supported by intensive treatment and rehabilitation, gave a satisfactory result in a relatively short period.

\section{References}

1. Inagawa T, Hirano A. Autopsy study of unruptured incidental intracranial aneurysms. Surg Neurol. 1990;34:361-5. http:// dx.doi.org/10.1016/0090-3019(90)90237-J.

2. Cianfoni A, Pravata E, De Blasi R, Tschuor CS, Bonaldi G. Clinical presentation of cerebral aneurysms. Eur J Radiol. 2013;82:1618-22. doi: 10.1016/j.ejrad.2012.11.019.

3. Mohr G, Ferguson G, Khan M, Malloy D, Watts R, Benoit B, et al. Intraventricular hemorrhage from ruptured aneurysm. Retrospective analysis of 91 cases. J Neurosurg. 1983;58:482-7. doi: 10.3171/jns.1983.58.4.0482.

4. Barton E, Tudor J. Subdural haematoma in association with intracranial aneurysm. Neuroradiology. 1982;23:157-60. doi: 10.1007/BF00347560.

5. Biesbroek JM, Rinkel GJ, Algra A, van der Sprenkel JW. Risk factors for acute subdural hematoma from intracranial aneurysm rupture. Neurosurgery. 2012;71(2):264-8; discussion 8-9. doi: 10.1227/NEU.0b013e318256c27d.

6. Wirth FP. Surgical treatment of incidental intracranial aneurysms. Clin Neurosurg. 1986;33:125-35.

7. Ellamushi HE, Grieve JP, Jager HR, Kitchen ND. Risk factors for the formation of multiple intracranial aneurysms. J Neurosurg. 2001;94:728-32. doi: 10.3171/jns.2001.94.5.0728.

8. Backes D, Vergouwen MD, Velthuis BK, van der Schaaf IC, Bor AS, Algra A, et al. Difference in aneurysm characteristics between ruptured and unruptured aneurysms in patients with multiple intracranial aneurysms. Stroke. 2014;45:1299-303. doi: 10.1161/STROKEAHA.113.004421.

9. Molyneux AJ, Kerr RS, Yu LM, Clarke M, Sneade M, Yarnold JA, et al. International Subarachnoid Aneurysm Trial (ISAT) of neurosurgical clipping versus endovascular coiling in 2143 pa- tients with ruptured intracranial aneurysms: a randomised comparison of effects on survival, dependency, seizures, rebleeding, subgroups, and aneurysm occlusion. Lancet. 2005; 366:809-17. doi: 10.1016/S0140-6736(05)67214-5.

10. Solter VV, Breitenfeld T, Roje-Bedeković M, Supanc V, Lovrenčić-Huzjan A, Šerić V, et al. General recommendations for the management of aneurysmal subarachnoid hemorrhage. Acta Clin Croat. 2014;53:139-52.

11. Seibert B, Tummala RP, Chow R, Faridar A, Mousavi SA, Divani AA. Intracranial aneurysms: review of current treatment options and outcomes. Front Neurol. 2011;2:45. doi: 10.3389/ fneur.2011.00045.

12. Hunt WE, Hess RM. Surgical risk as related to time of intervention in the repair of intracranial aneurysms. J Neurosurg. 1968;28:14-20. doi: 10.3171/jns.1968.28.1.0014.

13. Sen J, Belli A, Albon H, Morgan L, Petzold A, Kitchen N. Triple-H therapy in the management of aneurysmal subarachnoid haemorrhage. Lancet Neurology. 2003;2:614-21.

14. Solter VV, Roje-Bedeković M, Breitenfeld T, Supanc V, Lovrenčić-Huzjan A, Šerić V, et al. Recommendations for the management of medical complications in patients following aneurysmal subarachnoid hemorrhage. Acta Clin Croat. 2014; 53:113-38.

15. Gelabert-Gonzalez M, Iglesias-Pais M, Fernandez-Villa J. Acute subdural haematoma due to ruptured intracranial aneurysms. Neurosurg Rev. 2004;27:259-62. doi: 10.1007/s10143004-0333-x.

16. Inamasu J, Saito R, Nakamura Y, Ichikizaki K, Suga S, Kawase $\mathrm{T}$, et al. Acute subdural hematoma caused by ruptured cerebral aneurysms: diagnostic and therapeutic pitfalls. Resuscitation. 2002;52:71-6. doi: 10.1016/S0300-9572(01)00433-6

17. Diringer MN, Bleck TP, Claude Hemphill J $3^{\text {rd }}$, Menon D, Shutter L, Vespa P, et al. Critical care management of patients following aneurysmal subarachnoid hemorrhage: recommendations from the Neurocritical Care Society's Multidisciplinary Consensus Conference. Neurocrit Care. 2011;15:211-40. doi: 10.1007/s12028-011-9605-9.

Sažetak

\begin{abstract}
KOMBINIRANO LIJEČENJE RUPTURIRANE ANEURIZME SREDNJE MOŽDANE ARTERIJE PRAĆENE SUBARAHNOIDNIM KRVARENJEM I AKUTNIM SUBDURALNIM HEMATOMOM U VIŠESTRUKOJ ANEURIZMATSKOJ BOLESTI KRVNIH ŽILA MOZGA: PRIKAZ SLUČAJA
\end{abstract}

\title{
N. Novaković, M. Lepić, Lj. Minić, K. Radenović, A. Rotim i L. Rasulić
}

Aneurizme krvnih žila na bazi mozga su žarišna patološka proširenja koja se obično nalaze na račvanju arterija. Mogu ostati klinički nijeme cijelog života. Klinička slika nastaje zbog rupture i krvarenja. Samo u 1,3\% slučajeva rezultira pojavom subduralnog hematoma, što je u vezi s izravnom interakcijom aneurizme i bazalne arahnoidne membrane. Višestruke aneurizme su prisutne u 15\% do 33\% bolesnika sa subarahnoidnim krvarenjem. Pristup ovakvim bolesnicima je složen, jer ne postoje specifični znaci koji bi ukazali na ili otkrili aneurizmu koja je rupturirala. Ovaj prikaz opisuje bolesnicu u dobi od 44 godine s višestrukom aneurizmatskom bolešću mozga koja je nakon rupture hitno podvrgnuta endovaskularnom (zbog višestrukih aneurizma) i kirurškom (zbog akutnog subduralnog hematoma) terapijskom zahvatu u istom aktu u općoj anesteziji, što je rezultiralo njezinim potpunim oporavkom.

Ključne riječi: Intrakranijska aneurizma; Ruptura - terapija; Subduralni hematom; Prikazi slučaja 